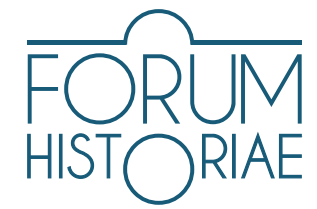

\title{
Italy, the Paris Peace Conference and the Shaping of Czechoslovakia
}

\author{
Francesco Caccamo
}

\begin{abstract}
CACCAMO, Francesco. Italy, the Paris Peace Conference and the Shaping of Czechoslovakia.

In the aftermath of the First World War, relations between Italy and the new Czechoslovak state rapidly took a turn for the worse. The Italians were irritated by widespread sympathy demonstrated by Czechs and Slovaks toward the Southern Slavs and by the Francophile alignment of Prague leadership. Moreover, Italy was convinced that Czechoslovakia was trying to establish a regional preeminence in East-Central Europe and therefore preferred what it considered a more balanced settlement. Subsequently, at the Paris Peace Conference Italy was the only great victorious power to voice criticism vis-à-vis the territorial claims of the new state, first, during the preliminary exam in the Commission for Czechoslovak Affairs, then during the decision-making process in the Supreme Council. Although the Italian representatives remained cautious about the German presence in the Czech Lands, they expressed significant reservations toward the territorial settlements in southern Slovakia, Subcarpathian Ruthenia and Teschen, and strongly contested the hypothesis of a corridor with Yugoslavia reaching the Adriatic coastline.
\end{abstract}

Keywords: Czechoslovak Republic 1918-1938, Paris Peace Conference, Italian-Czechoslovak relations, Italian foreign policy 1918-1922

DOI: https://doi.org/10.31577/forhist.2021.15.1.2

\section{Italy and the new Czechoslovak state on the eve of the peace conference}

Cholarly references to Italy's participation in the Paris Peace Conference generally $\checkmark$ focus on its territorial claims and on the Adriatic question. ${ }^{1}$ This creates the impression that, apart from hostility to the new-born Kingdom of the Serbs, Croats and Slovenes, the Italians lacked a policy for the East-Central European settlement that

This essay develops, integrates and updates research undertaken by the author in a previous work, CACCAMO, Francesco. L'Italia e la «Nuova Europa». Il confronto sull'Europa orientale alla conferenza di pace di Parigi (1919-1920), Milano; Trento : Luni Editrice, 2000.

1 On the Italian participation in the peace conference, the reference text still remains ALBRECHT-CARRIÉ, René. Italy at the Paris Peace Conference. New York : Columbia University Press, 1938; moreover BURGWYN, H. James. The Legend of Mutilated Victory: Italy, the Great War and the Paris Peace Conference. Westport : Greenwood Press, 1993; In Italy there is not a single exhaustive contribution on the peace conference, but the subject is dealt with in a considerable number of studies: VIVARELLI, Roberto. Il dopoguerra in Italia e l'avvento del fascismo. Napoli : Istituto Italiano per gli Studi Storici, 1967; PASTORELLI, Pietro. L’Albania nella politica estera italiana 1914-1920. Napoli : Jovene, 1970; MELCHIONNI, Maria Grazia. La vittoria mutilata. Problemi ed incertezze della politica italiana sul finire della Grande Guerra. Roma : Edizioni di Storia e Letteratura, 1981; PETRACCHI, Giorgio. La Russia rivoluzionaria nella politica italiana. Le relazioni italo-sovietiche 1917-1925. Bari : Laterza, 1982; ROSSINI, Daniela. L'America riscopre l'Italia. L'Inquiry di Wilson e le origini della Questione Adriatica, 1917-1919. Roma : Edizioni Associate, 1992; GARZIA, Italo. L'Italia e le origini della Società delle Nazioni. Roma : Bonacci, 1995; CACCAMO 2000; MONZALI, Luciano. Italiani di Dalmazia, 1914-1924. Firenze : Le Lettere, 2007; CATTARUZZA, Marina. L'Italia e la questione adriatica: dibattiti parlamentari e panorama internazionale (1918-1926). Bologna : il Mulino, 2014; BUCARELLI, Massimo. Mussolini, la questione adriatica e il fallimento dell'interventismo democratico. In Nuova Rivista Storica, 2011, Vol. 95, No. 1, pp. 137-205; LEFEBVRE D’OVIDIO, Francesco. L'Italia e il sistema internazionale. Dalla formazione del governo Mussolini alla grande depressione (1922-1929). Vol. 1. Roma : Edizioni di Storia e Letteratura, 2016, pp. 63-137. 
was being shaped in the French capital. ${ }^{2}$ This is true only up to a point. Although the Italians were conditioned and sometimes even absorbed by the pursuit of their aspirations on the eastern shore of the Adriatic, they did attempt to formulate an autonomous position on more general issues concerning the "new Europe". The primary challenge was that their interests were not always aligned with those of the rest of the victorious coalition. Factors like their geographical proximity to the Danube region and the Balkan peninsula, the break-up of a traditional rival like the Habsburg Empire, the emergence of a Yugoslav state claiming most of the eastern Adriatic and intimately tied to France, led the Italians to consider with serious reservations the attempt to create a new order, based not simply on the principle of nationality, as it is often claimed, but rather on the predominance of the small and medium powers identifiable with the cause of the victors. Unlike the Americans, English and mainly the French, the Italians were only partially interested in the creation of a barrière de l'Est against Germany and its possible allies and preferred the establishment of some sort of balance of power among the various actors in the region, both victors and vanquished. Obviously, such political orientation aimed to widen Italy's margin for maneuvering and encourage the spread of its economic and political influence in East-Central Europe. In the longer term, however, this positioning could also have provided an opportunity for reducing the national and territorial rivalries plaguing the region. ${ }^{3}$

This framework deeply affected the stance taken by the Italian representatives toward Czechoslovakia at the Paris Peace Conference. As a premise, it is worth remembering that, during the last phase of the war, the Italians seemed to develop positive relations with the Czechoslovak National Council (CNC) based in Paris and with its leaders, Tomáš Garrigue Masaryk, Edvard Beneš and Milan Rastislav Štefánik. Through the convention signed with Štefánik in Rome on 21 April 1918, the Italians formalized a collaboration with the CNC against Austria-Hungary and agreed with the creation of an autonomous military corps composed of Czech and Slovak war prisoners and volunteers. The so-called Czechoslovak legion reached a count of over twenty thousand men and was successfully deployed on the Alpine front during the final weeks of the conflict. Following the end of the hostilities, the legionnaires were sent to Prague under the command of a mission of Italian officers led by general Luigi Piccione and became the first organized military unit present in Czechoslovakia. Immediately afterwards they were charged with the fundamental task of taking control of Slovakia. Simultaneously Italy organized, armed and equipped the sixty thousand remaining Czech and Slovak prisoners of war present in the Apennines peninsula and sent them back to their homeland, while also providing the new state with shipments of food and various other materials. ${ }^{4}$

Needless to say, the Italians depended on this political and material support in order to establish a lasting influence over Czechoslovakia and to strengthen their position vis-a-vis the whole of East-Central Europe. They especially appreciated the importance of Czecho-

2 LEDERER, Ivo. Yugoslavia at the Paris Peace Conference: A Study in Frontiermaking. New Haven; London : Yale University Press, 1963; MONZALI, Luciano. Il sogno dell'egemonia. L'Italia, la questione jugoslava e l'Europa centrale (1918-1941). Firenze : Le Lettere, 2010.

3 Apart CACCAMO 2000, see CACCAMO, Francesco. Searching for a Policy for the New Europe: Italy and the Eastern European Settlement at the Paris Peace Conference. In VARSORI, Antonio - ZACCARIA, Benedetto (eds.), Italy in the New International Order, 1917-1922. London : Palgrave Macmillan, 2020, pp. 205-227.

4 PICHLÍK, Karel - KLÍPA, Bohumir - ZABLOUDILOVÁ, Jitka. I legionari cecoslovacchi (1914-1920). Trento : Museo Storico di Trento, 1997 ( $1^{\text {st }}$ edition 1996); for a new and original analysis, VOLPATO, Alessandro. I legionari cecoslovacchi in Italia. PhD dissertation, University "Sapienza” of Rome, 2021. 
slovakia's economy and hoped to attract a substantial quota of the trade emanating from its industrial core in Bohemia to the northern Adriatic port of Trieste (Terst). The Italian expectations were perhaps best expressed in a message drafted by the President of the Council Vittorio Emanuele Orlando at the end of 1918, entitled "To the People of Bohemia (sic)". Here Orlando paid homage to "the heroism without equal that allowed the Bohemian nation to conquer her independence and her freedom" and formulated the most optimistic previsions for the future: "This bond of friendship and affection that so intimately ties the souls of the two nations regardless of distance, will remain strong over time. Nothing will be able to weaken it, even less to destroy it; on the contrary, thanks to the common will, it shall grow stronger and more solid."

As a matter of fact, at the time Orlando wrote this message relations between Rome and Prague were already deteriorating. ${ }^{6}$ The Italians were puzzled by the discovery that the Czech and Slovak political representatives who had spent the war in their homeland and the public opinion at large nurtured feelings of sympathy for the Southern Slavs and supported their aspirations on the eastern Adriatic coast. The leaders of the CNC were more cautious, but even they manifested their desire for a compromise based on ethnic principle and for the attribution of at least northern Dalmatia, Fiume (Rijeka) and eastern Istria to the Yugoslavs. ${ }^{7}$ From the Italian perspective, projects aimed at connecting Czechoslovakia with the Kingdom SCS and subsequently with the Adriatic Sea through the districts of western Hungary were especially disturbing. For the Italians, the so-called Czechoslovak-Yugoslav corridor raised the specter of the creation of a Slavic bloc on the ashes of the Habsburg Empire, even of a Danubian confederation, capable of cutting Italy out of the East-Central European space and to contest its preeminence over the Adriatic Sea. Moreover, had Italy not obtained Fiume, the corridor could have seriously weakened the commercial position of Trieste. Revealingly, these kinds of concerns were expressed not only within Italian military and diplomatic circles ${ }^{8}$, but also by representatives of the politica delle nazionalità, the same ones that, during the war, had advocated for an alliance with the "oppressed nationalities" against Austria-Hungary and enthusiastically supported the creation of the Czechoslovak legion. For instance, the writer and journalist Giuseppe Antonio Borgese could not hide his disappointment after meeting twice with Beneš in December 1918. Even independent from the corridor issue, the new Czechoslovak foreign minister seemed to

5 Vittorio Emanuele Orlando, Al popolo di Boemia, 12 December 1918, reproduced in BIAGINI, Antonello - MUSIL, Miroslav (eds.) Milan Rastislav Štefánik alla luce degli archivi italiani. Bratislava : Nadácia pre záchranu kultúrneho dedičstva, 2012, pp. 72-73.

6 CACCAMO, Francesco. L'Italia nella corrispondenza tra Masaryk e Beneš all'indomani della prima guerra mondiale. In Clio, 1996, Vol. 22, No. 3, pp. 489-513; BOLECH CECCHI, Donatella. Alle origini di un'inimicizia. Italia-Cecoslovacchia 1918-1922. Soveria Mannelli : Rubbettino, 2008.

7 I Documenti Diplomatici Italiani (DDI). Roma : Tipografia dello Stato, 1954-, Series VI, Vol. 1, doc. 110, Bonin Longare to Sonnino, 11 November 1918. For the Czechoslovak standpoint, see Dokumenty Československé zahraniční politiky (DČZP). Praha : Ústav mezinárodních vztahů; Karolinum; Historický ústav AV ČR, 1994, Series A, Vol. 2, Tome 1, docs. 20 and 23, Hodža to the Foreign Ministry, 27 November 1918, and Beneš to Kramář, 29 November 1918 (quoting a statement by the social-democratic leader Vlastimil Tusar, according to which Trieste "must remain Slavic"). For his side, Beneš invited his compatriots to be cautious and to consider that Italy was a great power, therefore not to make it feel undervalued in comparison with France and Yugoslavia: DČZP, A, 2, 1, doc. 74, Beneš to Švehla, 19 January 1919. As a matter of fact, the dispositions of the foreign minister were not substantially different from those of his compatriots. The chargé d'affaires in Rome described in the following terms "Beneš line and mine" toward the Italians: "not to speak clearly, leave them some hope, in short, not push them away, until we need them for our prisoners of war and for our economic needs". DČZP, A, 2, 1, doc. 111, Borský to Kramár, 10 February 1919.

8 DDI, 6, 2, doc. 141, Badoglio to Orlando, Sonnino and Barzilai, 28 January 1919; MALAGODI, Olindo. Conversazioni della guerra (1914-1919), Vol. 1. Edited by Brunello Vigezzi. Milano; Napoli : Ricciardi, 1960, Vol. 1, pp. 499-501. 
cultivate the concept of "a new Central European system with Bohemia at its head", which was thought to be hardly compatible with Italian interests. ${ }^{9}$

Over the following weeks, other problems began to surface. In February 1919, the Italians were taken aback by the arrival of a French military mission in Prague led by general Maurice Pellé, by the evident political intimacy that it enjoyed with the Czechoslovak authorities and by the appointment of Pelle himself as chief of staff of the Czechoslovak army. ${ }^{10}$ They would have been even more disappointed had they known that Beneš had already conceived plans for putting the French in charge of the organization of the new Czechoslovak army and was forging lasting political bonds with Paris without any consideration for the mission of Piccione or the Italian interests in East-Central Europe. Indeed, the line of conduct followed by the Czechoslovak foreign minister was clear since the end of the war: "our future military organization must be put under French influence for political reasons, because France will have an exceptional influence at the peace conference and France will always support us in everything." 11

Other difficulties were raised by the discovery of the extent of Czechoslovakia's territorial claims. Beneš lobbied the great victorious powers in order to obtain support for the Czechoslovak program at the Peace Conference and received wide-ranging assurances from the French. However, he carefully avoided approaching the Italians, "so that they could not ask for compensations in exchange" ${ }^{12}$ Despite being uncertain about the full extent of Prague's ambitions, the Italians became increasingly suspicious of the Czechoslovak occupation of regions either ethnically mixed or mostly inhabited by other populations. ${ }^{13}$ For them, the advance of Czechoslovak troops led by the Piccione mission in areas of Slovakia with a strong Magyar presence was especially telling. Italian officers grew more and more skeptical about the compatibility of the Czechoslovak claims with the principle of nationality and in some cases did not conceal their sympathy for the Magyars. For their part, the Czechoslovaks reacted by expressing doubts about the reliability of the Italian mission and staged demonstrations against it. ${ }^{14}$

In this rapidly worsening atmosphere, the authoritative Italian foreign minister Sidney Sonnino, expressed his doubts about the opportunity to allow the return home of the Czech and Slovak prisoners of war that had been organized militarily in Italy, "till when we are able to better understand the attitude of its [Czechoslovakia's] representatives in Paris for what concerns the Adriatic questions, in connection with Yugoslavia." 15 Only after some hesitation Sonnino authorized the return of these POWs, but with "weapons and ammunitions in [an] amount [only] strictly necessary" ${ }^{16}$ For his part, the chief of the commission for the armistice in Vienna, General Segre, believed that Italy should support Czechoslovakia's

9 ALBERTINI, Luigi. Epistolario 1911-1926, Vol. 3. Edited by Ottavio Barié. Verona : Mondadori, 1968 , docs. 945 and 949, Borgese's reports, 17 and 20 December 1918.

10 Apart from CACCAMO 1996, see also LENZI, Francesca Romana. L'Italia e la Cecoslovacchia nel primo dopoguerra. In VALENTE, Massimiliano (ed.) Santa Sede ed Europa centro-orientale tra le due guerre mondiali. Soveria Mannelli : Rubbettino, 2011, pp. 117-142.

11 DČZP, A, 2, 1, doc. 41, Beneš to the Czechoslovak National Council, 9 November 1918.

12 DČZP, A, 2, 1, doc. 55, Beneš to Kramář, 30 December 1918.

13 DDI, 6, 2, doc. 184, Segre to Badoglio, 31 January 1919.

14 DDI, 6, 2, docs. 310 and 424, Lago to Sonnino, 11 February 1919, and Badoglio to Orlando, Sonnino and Caviglia, 21 February 1919. See also DČZP, A, 2, 1, docs 106 and 107, Presidium of the Council of Ministers to Kramár, and Štěpánek to Beneš, 6 February 1919.

15 DDI, 6, 1, doc. 877, Di Robilant to Orlando, 16 January 1919.

16 DDI, 6, 2, doc. 344, Sonnino to the Foreign Ministry, 15 February 1919. 
consolidation, but at the same time specified that it should also avoid entering into a conflict with the Austro-Germans and the Magyars because of the new state. ${ }^{17}$

\section{The debate in the Commission for Czechoslovak Affairs}

Italy's doubt and puzzlement increased following the opening of the Paris Peace Conference and especially the presentation of the Czechoslovak demands before the highest body of the conference, the Supreme Council, or in its first iteration, the Council of Ten. ${ }^{18}$ During their exposé on 5 February 1919, Beneš and Prime Minister Karel Kramář claimed the Czech Lands with over three million Germans on the grounds of historical considerations; the Duchy of Teschen (Těšín, Cieszyn) with its coal basin and with a considerable Polish minority for economic and historical reasons; the territory of Slovakia with 560 thousand Magyars (in actuality more than 800 thousand), on the grounds of the principle of nationality; Subcarpathian Ruthenia with its mostly Ruthenian or Ukrainian population in exchange for the concession of autonomous status. The Czechoslovak delegates also mentioned the corridor with Yugoslavia through the western Hungarian districts. Beneš called it a simple suggestion and offered alternative options such as the establishment of an international administration over the region or the internationalization of the railways that crossed it. However, the idea of direct territorial connection was developed in a specific memorandum addressed to the Peace Conference, Le voisinage des Tchécoslovaques et des Yougoslaves. The memorandum highlighted the presence of a Slav minority in the western Hungarian districts, the advantages stemming from the separation of two enemy peoples like the Magyars and the Germans and the economic benefits resulting from the concession of an outlet to the Adriatic Sea via Yugoslavia to Czechoslovakia. In the eyes of the Italians, the situation was worsened by the presentation of a map showing the envisioned Czechoslovak borders where Fiume, Istria, Trieste and Gorizia (Gorica) were all represented as part of Yugoslavia. ${ }^{19}$

Following the procedure adopted in Paris for minor countries identified with the victorious coalition, a preliminary examination of the Czechoslovak claims was conferred to a commission of technical delegates or experts. Italy was represented here by one of its plenipotentiary delegates, the Senator and former ambassador to Paris Giuseppe Salvago Raggi, and by the consul Augusto Stranieri, who had developed a specific competency on nationalities issues through long stays in the Balkans. Interestingly enough, the Czechoslovak delegation was thrilled to receive news about the composition of the commission but exhibited considerable consternation about the two Italians. The French (Jules Cambon and Jules Laroche), American (Charles Seymour and Allen Dulles), and British represen-

17 Archivio Storico-Diplomatico del Ministero degli Affari Esteri (ASMAE), Fondo Affari Politici 1919-1930, b. 932, General Segre, Report no. 4 of the commission for the armistice in Vienna, Presente situazione e progetti czeco-slovacchi, 26 January 1919.

18 For Czechoslovakia's participation in the Paris Peace Conference, the classic study remains PERMAN, Dagmar. The Shaping of the Czechoslovak State. Diplomatic History of the Boundaries of Czechoslovakia 1914-1920. Leiden : Brill, 1962. See also DEJMEK, Jindřích (ed.) Zrod nové Evropy: Versailles, St. Germain, Trianon a dotváření poválečného mírového systému. Praha: Historický ústav, 2011. This volume includes a chapter on Italy by Ondřej Houska, pp. 305-320, that, however, focuses on the developments in the 1920s rather than on the peace conference.

19 Papers on Foreign Relations of the United States, The Paris Peace Conference (FRUS, PPC). Washington : United States Government Printing Office, Council of Ten, 5 February 1919; DČZP, A, 2, 1, Report of the Czechoslovak delegation, 7 February 1919, doc. 108. On the importance of the corridor for the Czechoslovak delegation, see DČZP, A, 2, 1, Analysis of the Czechoslovak delegation at the Paris Peace Conference on the Czechoslovak borders under the military-strategic viewpoint, 20 January 1919, doc. 76. For Italy's protests on the above-mentioned map, DDI, 6, 2, doc. 469 and footnote 2, Sonnino to Lago, 7 February 1919, and Lago to Sonnino, [...] February 1919. 
tatives (Joseph Cook and Arthur Nicholson) were enthusiastically described as "friends, with whom we have been in touch for a long time and who share our point of view". On the contrary, the Italians received just a curt comment: "Only the Italian delegates remain."

The Commission on Czechoslovak Affairs came into effect at the end of February. The first issue under scrutiny was the delimitation of the Czech Lands and the fate of the large local German population. Faced with the tendency of the representatives of the other powers to privilege historical, economical and geographical considerations over ethnic ones, Salvago Raggi could not help wondering: "Don't we run the risk of excessively Germanizing the new State, if we include this German population in Bohemia?" Nonetheless, the Italian plenipotentiary preferred not to insist. Especially after Cambon stressed the necessity of giving the Czechs full control of the mountain chains surrounding Bohemia in order to ensure their protection against Germany, Salvago Raggi readily recognized the importance of this strategic criteria. ${ }^{21}$ Obviously, Salvago Raggi was mindful of the relevance of strategic considerations for the Italian claims on the Alps and on the Eastern Adriatic. By supporting their application in the Czechoslovak case, he was establishing a precedent that he hoped could be applied when the Italian requests would come up for discussion. At the same time, Salvago Raggi conformed himself to the reserved stance that Italy adopted in almost all matters concerning Germany, in the hopes of reciprocation in a similar way when the Adriatic question came under scrutiny. The Italians maintained this line of conduct when the commission examined the delimitation of the Czech Lands in greater detail. After having initially agreed with the Americans on the opportunity to give Germany at least some areas with a clear German majority, such as the district of Eger (Cheb) and especially the saillant of Asch (Aš), Salvago Raggi and Stranieri ended up accepting the AngloFrench proposal of preserving the pre-war border division of Austria from Germany. In the end the Italians acquiesced even to a rectification beyond the historical delimitation of the Czech Lands, allowing Prague to obtain the Austrian locality of Gmünd with its railway junction. ${ }^{22}$

The Italians turned out to be more resolute when the Slovak-Hungarian border was examined. From the outset, Salvago Raggi demanded that the border be established as close as possible to the ethnic line: "One should not include in Czechoslovakia too many Magyar elements, in order not to modify the character of its population." As he noted, the number of Magyars claimed by Czechoslovakia, which he estimated to be 860 thousand, was not too high in itself, but was certainly excessive compared to a Slovak population of allegedly 2.7 million people. ${ }^{23}$ The Italians concentrated mainly on two areas claimed by Czechoslovakia: the Danubian island of Grosse Schütt (Žitný ostrov, Csallóköz), and the minor mountainous reliefs in the proximity of Budapest. In the first case, they demanded that the island with its compact nucleus of 90 thousand Magyars remain within Hungary, disregarding Anglo-French support for the defensive needs of what at the time was mainly

20 DČZP, A, 2, 1, doc. 108, Report of the Czechoslovak delegation, 7 February 1919.

21 Conférence de la Paix. Recueil de Actes de la Conférence de la Paix (Recueil), IV C 1. Paris : Imprimerie National, 1920, p. 8-12, Commission for Czechoslovak Affairs, 27 February 1919 (No. 1). The Recueil is a confidential edition prepared by the French government during the peace conference and distributed only to the delegations of the great victorious powers. For the present work, I used the copy preserved in ASMAE, Conferenza della Pace.

22 Recueil, IV C 1, pp. 143-153 and 154-160, Sub-Commission for Czechoslovak Affairs, 11 and 13 March 1919 (Nos. 6 and 7).

23 Recueil, IV C 1, pp. 14-16, Commission for Czechoslovak Affairs, 28 February 1919 (No. 2). See also pp. 27-30, 5 March 1919 (No. 4). 
known as Pressburg or Poszony (Prešporok, Bratislava). "He understands," argued Salvago Raggi, "that, when there are elements of uncertain nationalities, they are given to friends rather than enemies, but, when almost all of the population belongs to the same race, the defensive argument becomes secondary." As a matter of fact, Italy's interest for the Grosse Schütt was motivated by the possibility that the island, situated just above the western Hungarian districts, might become the base for the Czechoslovak-Yugoslav corridor. In the second case, the Italians wanted to prevent Czechoslovakia from taking possession of the hills north of Budapest, in order to avoid the new border running in proximity to the Hungarian capital. Despite resolute support by the French and British to the Czechoslovak demands, the Italians reached a common position with the Americans in order to contain Hungarian losses. According to a joint Italian-American proposal, Czechoslovakia was to obtain the Grosse Schütt, but the border in proximity to Budapest was to be moved $20 \mathrm{~km}$ further north than originally planned, along the course of the river Eipel (Ipoly). Moreover, at Slovakia's easternmost fringe, the center of Satoralja with its mostly Magyar inhabitants was to be left to Hungary. As Stranieri would sum up later, through this compromise the Italians abandoned defense of the Grosse Schütt but were able to ensure that Hungary maintained control over territories inhabited by 150 thousand Magyars. ${ }^{24}$

The Italians were less successful with Subcarpathian Ruthenia. In this case the British, French and Americans agreed with the opportunity to follow the Czechoslovak proposals and confer Prague control over the region with a specific autonomy. For them, this solution offered the advantage of linking two friendly states such as Czechoslovakia and Romania territorially at the expense of enemy Hungary. Only Salvago Raggi objected, finding it contrary to Hungary's complete encirclement and the severance of all connections with Poland. For him, it was better to leave Ruthenia to Hungary, although still with some form of autonomy: "He can't see how friendly relations could be established by giving Czechoslovakia this corner of land. As it must be stressed, this solution will put an end to all the connections of Hungary and Romania with Poland and vice versa. Since we agreed that the Ruthenes will remain anyway independent [sic: autonomous], why don't we unite them to the neighbors with whom they have some economic, strategic or political reasons to be united, that is to say, the Hungarians?" Even after his proposal was rejected, Salvago Raggi kept calling the union of Ruthenia with Czechoslovakia "a bad solution". At least subordinately, he expressed his support for the American requests aimed at foreseeing concrete guarantees for Ruthenia's autonomy and, moreover, at creating an ad hoc regime for Polish-Hungarian communications through the region. ${ }^{25}$

Needless to say, the Italians resolutely opposed the Czechoslovak-Yugoslav corridor through the western Hungarian districts. At Salvago Raggi's urging, the Commission drafted a statement that rejected this idea and suggested that the Supreme Council might consider

24 Recueil, IV C 1, pp. 19-35, 26-30, 34-36, 130-132, 133-134, 136-142, Commission for Czechoslovak Affairs, 3, 5 and 8 March 1919 (Nos. 3, 4, 5), and Sub-Commission for Czechoslovak Affairs, 4, 5 and 7 March 1919 (Nos. 3, 4, 5); ASMAE, Fondo Conferenza della Pace, b. 3, Stranieri's Report for Tittoni, Frontiere dello Stato Czeco-Slovacco, 28 August 1919.

25 Recueil, IV C 1, pp. 16-18 and 81, Commission for Czechoslovak Affairs, 28 February and 19 March 1919 (Nos. 2 and 9). The issue of Ruthenia was also raised in the Commission for Romanian and Yugoslav affairs at the beginning of March. Here, the Italians suggested that the eastern part of the region be given to Romania in order to maintain at least some connection between Romania and Poland, but their proposal was sharply rejected by the representatives of the other powers: Recueil, IV C 4, pp. 81-82. 
other means for facilitating trade between Czechoslovakia and the Adriatic. ${ }^{26}$ Nonetheless, discussions were not over yet. Following the procedure established in Paris, the report of the Czechoslovak Commission was submitted for a final review to the Central Committee for Territorial Questions. This provided an authoritative member of the French delegation, such as André Tardieu, the opportunity to relaunch the idea of the Czechoslovak-Yugoslav corridor as an instrument for Hungary's containment. This seems to prove that the corridor was something more than a mere theoretical proposal and that it enjoyed substantial support within French political circles. Only thanks to the objection of his American colleague Sidney Mezes, Salvago Raggi (who happened to represent Italy in the Central Committee as well) had the chance to prevent approval of Tardieu's proposal. Together, Salvago and Mezes pointed out that the corridor would run through territories inhabited mostly by non-Slav populations and would not be defensible in the case of an outbreak of hostilities: "the barrier would be very frail and the countries where the corridor could be established are not inhabited by a Slav majority." ${ }^{27}$

The last claim to be examined concerned the Duchy of Teschen and its rich coal basin. The issue raised delicate political problems because in this case Czechoslovakia faced another country identified with the victorious coalition such as Poland. It also involved technical issues since it fell under the competency of a plurality of technical bodies; apart from the Commission for Czechoslovak Affairs and its Polish counterpart, there was also a commission that the Council of Ten had sent directly to Teschen in January 1919 in an attempt to prevent an outbreak of hostilities. On its return to Paris, this Inter-allied Commission for Teschen decided to express its views on the future of the region. In a specific report, the British and American representatives, alongside their Italian counterpart, Colonel Antonio Tissi, supported the creation of a small independent state, but did not fail to mention the existence of a predominantly Polish population. On the contrary, the French representative reiterated his country's pro-Czech stance and asked that the whole region be placed under Prague's control. ${ }^{28}$

At the end of March, the two Commissions for Czechoslovak and Polish Affairs met in a joint session to examine this report. ${ }^{29}$ All sides rejected the proposal to create a small and hardly viable independent state, but otherwise there was no consensus. The French reiterated their support for the attribution of the whole region to Czechoslovakia, but the Italians, both Salvago Raggi and his colleague from the Polish Commission, Pietro Tomasi della Torretta, stressed the existence of a Polish majority. In this way, the Italians avoided immediate approval of the French proposal favorable to Czechoslovakia, which allowed the continuation of what by now was called the Joint Commission for Teschen. ${ }^{30}$ In the following days, the French alongside the British continued to favor the attribution of Teschen to the Czechs on the grounds of historical and economic considerations. Nonetheless, the Italians gained American support for a division based on the principle of nationality. For a moment, the Italians and the Americans seemed able to manifest their

26 Recueil, IV C 1, pp. 38-40, Commission for Czechoslovak Affairs, 8 March 1919 (No. 5).

27 Recueil, IV C 8, p. 28, Central Committee for Territorial Questions, 25 March 1919 (No. 8); Stranieri's Report for Tittoni, Frontiere dello Stato Czeco-Slovacco, 28 August 1919.

28 Recueil, IV C 3, pp. 3-4, Inter-allied Commission for Teschen, 26 March 1919.

29 In the previous days, the Commission on Polish affairs had already started to debate the Teschen issue within a specific sub-committee for Poland's western border. Since the Italian representative was not present, however, he refused to recognize the validity of what had been discussed.

30 Recueil, IV C 3, pp. 5-10, Joint Commission for Teschen, 31 March 1919 (No. 1). 
common position in a project representing a viable compromise, leaving Poland a majority of the population and Czechoslovakia most of the coal basin. ${ }^{31}$ This possibility, however, was frustrated by hesitation of the Americans and their eventual realignment with the Czechoslovakophile views of the majority. Left isolated, the Italians kept insisting on an ethnic division and warned that different solutions risked "perpetuating insurmountable difficulties and a state of latent crisis". The split was formalized on 6 April when the Joint Commission prepared a note expressing the two different standpoints. The French, British, Japanese and also the Americans demanded the attribution of three-quarters of the district and almost all of its coal basin to Czechoslovakia, while the Italians reiterated their belief that it would be more equitable to leave Poland the majority of the population and at least a portion of its coal production. ${ }^{32}$

With this, the examination of the Czechoslovak claims was essentially completed. Subsequently, we shall see how proposals prepared by the experts were received by the plenipotentiary delegates gathered in the Supreme Council. Before that, however, it is still worth mentioning some developments that affected Italian-Czechoslovak relations at the peace conference. First of all, it is good to keep in mind that although the activities of the territorial commissions were supposed to be strictly confidential, Beneš was constantly briefed on discussions concerning Czechoslovakia by several friends he counted among the allied representatives, above all the French. The news he received made him very optimistic. As he commented: "[I]f we were left with these borders, it would mean for us a real triumph [...] none of the other smaller nations fulfilled its claims in such an integral way as we did." ${ }^{3}$

In this context, the only discordant note was provided by the Italians and the critical stance they had expressed toward some of the Czechoslovak claims. As a result, the entire Czechoslovak leadership developed a deep resentment toward the Italians. ${ }^{34}$ These negative feelings were expressed symptomatically in a letter addressed in mid-March by President Masaryk to American Secretary of State Robert Lansing. In it, Masaryk went so far as to denounce the behavior of the Italians in Paris as evidence of their tendency to collaborate with countries hostile to Czechoslovakia, undermining the whole process of the peace conference. As he explained, because of their resentment towards the Yugoslavs and their rivalry with the French, the Italians were getting closer not only to the Magyars, but also to the Germans and the Poles. In this situation, the president saw only one remedy: "The Czechoslovak Republic must be as strong as possible. The Entente must help us not only from the material but also from the moral point of view, at the Peace conference she must not only recognize but also stress the importance of our nation and of our state. The Magyars, the Poles, the Austro-Germans and the Italians must acknowledge this desire of the Entente. Only in this way will the Czechoslovak Republic be allowed to organize Eastern Europe according to the demands of the world situation." 35 After having

31 Recueil, IV C 3, pp. 141-144, Joint Sub-commission for Teschen, 2 April 1919 (No. 2).

32 Recueil, IV C 3, pp. 144-147, 148-152, 153-155, Joint Sub-commission for Teschen, 3, 4 and 6 April 1919 (Nos. 1 , 2 and 3); pp. 14-15 and 19-21, Joint Commission for Teschen, 5 and 6 April 1919 (Nos. 2 and 3); pp. 22-26, Note of the Joint Commission for Teschen, 6 April 1919.

33 DČZP, A, 2, 1, doc. 140, Beneš report to the Foreign Committee of the National Assembly, 7 March 1919. As Beneš added, if these results were to be confirmed, "the whole war and the conference will be a real political and diplomatic triumph".

34 Masaryk a Beneš ve svých dopisech z doby pařižských mirových jednání v roce 1919, Vol. 2. Edited by Zdeněk Šolle. Praha : Práce z dějin Ceské akademie věd, 1994, doc. 29, Beneš to Masaryk, 3 March 1919.

35 DČZP, A, 2, 1, doc. 152, Masaryk to Lansing, 16 March 1919. 
spoken with General Secretary of the French Foreign Ministry Philippe Berthelot, Beneš went even further. In a letter to Masaryk, he did not hesitate in depicting a gloomy scenario, with Italy and Czechoslovakia lined up on opposite sides in a future war: "I think we are going to be at war with the Germans, the Magyars and the Austrians, the Yugoslavs against the Italians, who would be with the Hungarians, the Austrians and the Germans. We should [go] with the French, the Poles and the Yugoslavs [...]. For this it is necessary to start getting ready for war."36

The other factor to consider was the outbreak of a veritable crisis concerning the Italian mission in Slovakia. Polemics generated by the alleged Magyarophile sympathies of the Italian officers and by the rivalry with the French mission led by general Pellé culminated during the conflict that opposed Czechoslovakia to the Hungarian Republic of Councils. After the initial success scored by the Hungarian Bolsheviks, the Italians were accused of incompetency in the best case, in the worst of plotting with the enemy. As a result, the Piccione mission found itself in an unbearable position and had to be withdrawn from Czechoslovakia at the beginning of June 1919. Things were made even worse by the tragic death of Štefánik, the representative of the Czechoslovak movement for independence who had proved to be better disposed towards Italy and had unsuccessfully tried to moderate the Francophile course advocated by Beneš. ${ }^{37}$

For their side, the Italians were increasingly worried by rumors about the existence of a Czechoslovak-Yugoslav military agreement directed against them. ${ }^{38}$ As we now know, it was not only fictional. Documentation available shows that, in the early summer of 1919, political and military circles in Belgrade actually proposed to Prague the conclusion of an alliance in order to contrast "German-Magyar-Italian intrigues" and to accomplish a fait accompli in western Hungary for establishing the Czechoslovak-Yugoslav corridor. ${ }^{39}$ Interestingly enough, Beneš did not consider the moment ripe for military action, but also did not object to Yugoslav reasoning. ${ }^{40}$

\section{The final decisions concerning Czechoslovakia's borders}

According to the plans originally conceived by the great powers, the experts from the territorial commissions were to make only a preliminary examination, open to full reconsideration by the plenipotentiary delegates gathered in the Supreme Council. As a matter of fact, the proposals of the commissions turned out to be much more binding than expected. Most were automatically accepted at the moment of the drafting of the peace treaties with the enemy powers. This was especially true in the case of the Commission for Czechoslovak Affairs, due to the general goodwill that surrounded the Czechoslovak delegation

36 ŠOLLE 1994, doc. 37, Beneš to Masaryk, 5 April 1919.

37 CACCAMO 1996; CACCAMO, Francesco, L’ultima missione di Milan Rastislav Štefánik alla luce delle nuove fonti. In CAPUZZO, Ester - CREVATO-SELVAGGI, Bruno - GUIDA, Francesco (eds.) Per Rita Tolomeo, scritti di amici, Vol. 2. Venezia : La Musa Talìa, 2014, pp. 207-228; KLIMEK, Antonín. Beneš a Štefánik. In Sborník $k$ dějinám 19. a 20. století, 1991, Vol. 12, pp. 35-66. On Štefánik, see the recent biography by KŠIŇAN, Michal. L'homme qui parlait avec les étoiles. Milan Rastislav Štefánik, héros franco-slovaque de la Grande Guerre. Paris : Eur'Orbem, 2019; on Beneš, the classic study is DEJMEK, Jindřich. Edvard Beneš. Politická biografie českého demokrata, 2 Vols. Praha : Karolinum, 2006-2008, but see also ZEMAN, Zbyněk - KLIMEK, Antonín. The Life of Edvard Benes: 1884-1948: Czechoslovakia in Peace and War. Oxford; New York : Oxford University Press, 1997; MARĖS, Antoin. Edvard Beneš, de la gloire à l'abîme: un drame entre Hitler et Staline. Paris : Perrin, 2015.

38 DDI, 6, 3, docs. 488, 748, 879.

39 DČZP, A, 2, 2, docs. 274 and 289, Šimek to the Foreign Ministry, 7 and 20 July 1919.

40 DČZP, A, 2, 2, doc. 300, Beneš to Machatý, 25 July 1919. 
and especially the resolute support it received from the French. Under these conditions, the Italian representatives in Paris had little room for maneuvering. More importantly, they were increasingly distracted by the opening of discussions concerning the Adriatic question in spring 1919, their dramatic clash with American President Woodrow Wilson and their subsequent two-week withdrawal from the Peace Conference (the so-called Adriatic crisis). ${ }^{41}$

The unassertive attitude of the Italians was evident during discussions concerning the peace treaty with Germany. When the newly instituted Council of the Big Four quickly ratified the proposals of the Czechoslovak Commission and decided to leave, unaltered, the historical border that divided Germany from the Habsburg Empire, and thus from the Czech Lands, Orlando did not raise any objection nor make any comments. The same occurred when proposals formulated by the experts were included practically without changes in the peace preliminaries with Austria and Hungary. On a few occasions though, the Italians did not shy away from expressing their views. This happened for instance when the question of Teschen was taken into consideration by the Council of Foreign Ministers, the body assisting the Council of Four. While the French insisted that most of the region and its coal basin should be given to Czechoslovakia, the Italians reiterated their support for a division more respectful of ethnic considerations and Polish interests. For the moment, the stalemate was broken by an American proposal, which sought to leave the search for a solution to direct negotiations between Prague and Warsaw. ${ }^{42}$

Another discussion was raised by a new Austrian request aimed at revising the border traditionally dividing Cisleithania from Transleithania and annexing the western Hungarian districts or, according to the German definition, the Burgenland, to Vienna. In the Council of the Foreign Ministers the majority was favorably disposed toward this idea, not so much because of the presence of a predominantly German population, but rather as a means for compensating Austria for other territorial losses and, above all, for dissuading it from pursuing the Anschluss. On the contrary, Sonnino warned that the proposed solution would threaten the positive relations entertained by the Austrians and the Magyars and introduce a further element for tension in East-Central Europe. Although he neglected to mention it, his opposition was due in good part to the desire to avoid any change of the status quo in the Burgenland, which might offer neighboring states an opportunity to interfere and raise anew the issue of the Czechoslovak-Yugoslav corridor. For this reason, Sonnino stressed that Austria and Hungary should be left free to reach an agreement directly between themselves, without interference: "He couldn't see a reason for inciting them [...]. He considered quite unnecessary to suggest them to raise superfluous problems. The two countries had never discussed their border for fifty years; their present governments were very unstable and this did not seem the right time to start a fight between them." ${ }^{43}$ Despite his colleagues' objections, for the moment Sonnino seemed able to prevail. In mid-May, a joint session of

41 On these developments, see the works quoted in footnote 1. Interestingly enough, Beneš claimed proudly that the postponement of the solution of the Adriatic question was due not only to opposition of the Yugoslavs, but also the help they received from the Czechoslovaks: DČZP, A, 2, 1, doc. 219, Beneš to the Foreign Committee of the National Assembly, 3 June 1919.

42 FRUS, PPC, 4, pp. 608-612, Council of the Foreign Ministers, 23 April 1919.

43 FRUS, PPC, 4, pp. 672-677, Council of the Foreign Ministers, 8 May 1919. 
the Council of the Big Four and the Council of Foreign Ministers decided that the AustroHungarian border was to remain unchanged, at least unless Vienna objected. ${ }^{44}$

By late spring 1919, the imminent conclusion of the treaty with Germany at Versailles and the absence of a solution for the Adriatic question exacerbated the Italian public's dissatisfaction and initiated a prolonged phase of political instability that further diminished the efficiency of the Italian line of conduct at the peace conference. In June, the OrlandoSonnino government fell and was substituted by a new cabinet led by Francesco Saverio Nitti, with Tommaso Tittoni simultaneously in charge of the Foreign Ministry and the Paris negotiations. Tittoni was critical toward his predecessors and was confident he could restore good relations with the other great powers, solving the Adriatic question at the price of some concessions. In the same context, Tittoni tried not to antagonize the East and Central-European countries linked to the victorious coalition and showed some interest for the overtures he received from Beneš as soon as he arrived in Paris. Nonetheless, his presence at the head of the Foreign Ministry was too short to seriously affect Italy's attitude toward Czechoslovakia and most of his collaborators remained critical toward Prague's demands..$^{45}$

This was apparent in the final phase of negotiations for the peace treaty with Austria and with the creation of a commission charged with examining Vienna's counterproposals. In this commission Italy was represented by Luigi Vannutelli Rey, who had acquired a certain expertise on East-Central Europe having served as consul in Budapest. Faced with resurgent requests to cede the Burgenland to Austria, Vannutelli Rey stuck to the position previously formulated by Sonnino and stressed the opportunity that the two parties involved negotiated, in full autonomy, an arrangement compatible with their interests. Vannutelli Rey's reaction was harsher when the French and British representatives proposed another modification to the upper fringe of the Burgenland, that is, the attribution of a bridgehead beyond the Danube to Czechoslovakia, in correspondence with Pressburg. For the AngloFrench, this solution had the advantage of avoiding the separation of Pressburg from the nearby urban development situated south of the Danube (present day Petržalka). Moreover, Slovakia's main city would obtain a railway connection with Zagreb and, further away, with the Adriatic. For his side, Vannutelli Rey pointed out that the bridgehead interrupted the natural frontier provided by the Danube and further weakened the strategic position of Budapest and Vienna vis-à-vis Czechoslovakia. He was also clearly worried that, by reducing the Burgenland's extension, the establishment of the abhorred Czechoslovak-Yugoslav corridor might become easier in the future. As he summed up: "It is already negative enough that Pozsony was attributed to the Czechs, although the majority of the population is Hungarian and the Slovaks are not numerous. It would be a senseless humiliation if now the Czechs were given a bridgehead as well." However, Vannutelli Rey's objections concerning both the Burgenland and the Czechoslovak bridgehead did not have any effect and he could only express his dissent with his colleagues. ${ }^{46}$

44 FRUS, PPC, 4, pp. 503-507, Council of Ten, 12 May 1919.

45 CACCAMO 2000, pp. 181-186; ALATRI, Paolo. Nitti, D’Annunzio e la questione adriatica (1919-1920). Padova : Feltrinelli, 1960; MICHELETTA, Luca. Italia e Gran Bretagna nel primo dopoguerra, Vol. 1. Roma : Jouvence, 1999, pp. 15-98. Tittoni's moderation toward Czechoslovakia might have been influenced by the overtures he received from Beneš: DDI, 6, 4, docs. 146 and 646, Tittoni to Lago, 23 July 1919, and Faralli to Tittoni, 24 October 1919.

46 The activity of the Commission for the exam of the Austrian counterproposals can be reconstructed through the following sources: FRUS, PPC, 7, appendix A, pp. 94-96, Report presented by the commission to the Council of the Head of Delegations, 10 August 1919; Papers and Documents Relating to the Foreign Relations of Hungary 1919-1920. Budapest : Royal Hungarian University Press, 1939, Vol. 1, doc. 14, Teleki to Sommsich, 23 Febru- 
When the new version of the Supreme Council, the Council of the Heads of Delegation, reviewed proposals formulated by the experts, it agreed without hesitation that the Burgenland was to be ceded to Austria. Tittoni, who had just arrived in Paris, did not want to antagonize his colleagues and abstained from reiterating the Italian position. The Czechoslovak bridgehead, however, was a different matter. The second Italian plenipotentiary delegate, Silvio Crespi, could not stop from observing: "He could not see a reason to allow Czechoslovakia's expansion beyond the Danube [...]. This would represent a permanent cause for dissent $[. .$.$] . The possession of an isolated bridgehead had an offensive aspect$ both toward Austria and Hungary. The Italian delegation would prefer to give satisfaction to the Czechs in whatever other region." Crespi also denied that the urban center beyond the Danube could be considered part of Pressburg and suggested that Czechoslovakia's connection to the Adriatic be satisfied through trade agreements rather than through territorial changes. Nonetheless, the Italians ended up accepting a proposal by Tardieu, according to which Czechoslovakia would obtain the bridgehead but would have to keep it demilitarized. From the Italian perspective, this solution had the advantage of at least limiting the possibility that the bridgehead might be exploited militarily against Budapest and Vienna. ${ }^{47}$

In the same period, the Teschen issue came once again to the fore. In July the Joint Commission for Teschen acknowledged that the direct negotiations between Prague and Warsaw had been fruitless and resumed its activity, in an attempt to produce a solution that could still be included in the Austrian peace treaty. ${ }^{48}$ In the meantime, the Inter-allied Commission physically present in Teschen drew up a new report supporting a partition at least partially considerate of ethnic considerations. The members of the Joint Commission could not help but notice the similarity between this new report and the minority position expressed in the last months by the Italians. All at once the British representative paid homage to the Italian clairvoyance, the American expressed his regret for not having supported the Italian thesis with enough determination in the past, and even the French delegate placed aside his Czechoslovakophile views momentarily. In this atmosphere, the Joint Commission approved unanimously a project that represented a compromise between the conflicting Czechoslovak and Polish aspirations. Specifically, Warsaw was to receive 171 thousand Poles and 10 thousand Czechs with about one third of the coal and coke mines, while Prague 105 thousand Czechs and 62 thousand Poles, with two thirds of the mines. ${ }^{49}$

ary 1920; ASMAE, Conferenza della Pace, b. 3, Report drawn by the Italian representatives on the meeting of the commission of 6 July 1919; Stranieri to Tittoni, Frontiere dello Stato Czeco-Slovacco. As it is worth noting, Beneš intervened in advance with the French in order to make sure that the Burgenland question be solved coherently with Czechoslovak plans. As he wrote, "if the Conference did not want to satisfy our original demands [by creating the Czechoslovak-Yugoslav corridor], it is absolutely necessary, in Europe's general interest, to think to a solution different from attributing this territory either to Hungary or to Austria." As he explained, what he had in mind was that the Burgenland "be neutralized or put under the League of Nations' administration." Beneš also demanded the acquisition of the bridgehead beyond the Danube in consideration of "the struggle of the Czechoslovak nation against Vienna and Budapest": DČZP, A, 2, 2, docs. 274 and 278, Beneš to Clemenceau, 3 and 10 July 1919.

47 FRUS, PPC, 7, pp. 94 and 97-100, Council of the Heads of Delegation, 10 and 11 July 1919.

48 Recueil, IV C 3, pp. 32-33, Joint Commission for Teschen, 24 July 1919.

49 Recueil, IV C 3, pp. 163-166, 167-170, 180-183, Joint Sub-commission for Teschen, 31 July, 12 August and 18 August 1919 (Nos. 7, 8, 10); pp. 40-43, Joint Commission for Teschen, 19 August 1919 (No. 6); pp. 51-58, Report of the Joint Commission for Teschen, 22 August 1919. 
As a matter of fact, the French were not satisfied and began immediately to maneuver in order to subvert this solution. First they set up an audition of the Czechoslovak and Polish representatives by the Council of Heads of Delegations, then they insisted on charging the Joint Commission for Teschen with a new exam. Faced with such an anomalous procedure, Tittoni did not raise serious objections and limited himself to wishing for a balanced judgement. In this way, perhaps, he was also trying to show good-will to Beneš, who had specifically asked for his support for Teschen. ${ }^{50}$ Under these circumstances, division among the members of the Joint Commission reemerged abruptly. The Italians, Americans and British remained favorable to an equitable division of Teschen, but the French resumed their traditional standpoint, preferring the attribution of most of the region to Czechoslovakia. The stalemate was overcome only by a proposal to determine Teschen's fate via a plebiscite. The proposal was approved by the Council of the Heads of Delegations after both the Poles and the Czechoslovaks had given their consent (for very different reasons though: the former hoped that a plebiscite would allow them to take advantage of the presence of a Polish majority, the latter simply wanted to gain time). ${ }^{51}$ In the end, the plebiscite was never to take place. After a series of postponements, in the summer of 1920 the conflict with the Russian Bolsheviks and the advance of the Red Army to the gates of Warsaw forced the Poles to ask for an arbitrage by the great powers. In the critical juncture determined by conflict with the Russians, everyone was convinced that Poland did not have alternatives to appeasing Czechoslovakia at the price of substantial concessions regarding Teschen. Subsequently, the French proposal favorable to the attribution of most of the region and its coal basin to Prague was finally able to prevail..$^{52}$

The last occasion to discuss the borders of Czechoslovakia was provided by the final round of talks concerning the peace treaty with Hungary in the first half of 1920. By then, Tittoni had already resigned, having realized that difficulties in Paris were much more complex than expected and that the goodwill he had tried to display toward both the great powers and the new East-Central European countries had not produced any positive effects. ${ }^{53}$ Although Nitti replaced Tittoni at the Foreign Ministry with Vittorio Scialoja, this time the Italian premier reserved for himself the negotiations concerning the peace settlement. For him, this was an occasion to implement the ideas he had developed in recent months on the necessity to facilitate European economic and political recovery by moderating the system of the peace treaties and favoring cooperation with the defeated countries. There is

50 FRUS, PPC, 8, pp. 80-82, Council of the Heads of Delegation, 3 September 1919. For Tittoni's contacts with Beneš on the question of Teschen, see Tittoni to Lago, 23 July 1919, already mentioned.

51 Recueil, IV C 3, pp. 60-68 and 69-72, Joint Commission for Teschen, 10 September 1919, and annexed Report from 11 September 1919; FRUS, PPC, VIII, pp. 184-185, Council of the Heads of Delegation, 11 September 1919; Archivio Centrale dello Stato (ACS), Rome, Carte Nitti, b. 31, Tittoni to Nitti, 11 September 1919.

52 It is worth pointing out that, during this last phase of the discussions concerning the Teschen issue, the Nitti government substituted Colonel Tissi in the Inter-allied commission present in the region with an influential personality, a member of the House of Representatives and former Undersecretary of State Luigi Borsarelli. Instructed to follow a neutral line of conduct among the Czechoslovaks and the Poles, Borsarelli kept signaling the partiality of the French representatives and their Czechoslovakophile leanings: ASMAE, Affari Politici 1919-1930, b. 933, Borsarelli's report without date (but arrived at the Foreign Ministry on 28 April 1920), or Borsarelli to Scialoja, 27 May 1920.

53 Tittoni's lack of success was visible also in relation to Czechoslovakia. Even if the Italian delegation had moderated its approach toward the Czechoslovak claims, Beneš did not show any gratitude. On the eve of the signature of the Treaty of St. Germain, he announced the decision to open negotiations for an alliance with the Kingdom SCS in the following terms: "Now we are completely free in regard of the peace conference and completely free in regard to Italy, therefore it is necessary to take a more autonomous position." See DČZP, A, 2, 2, doc. 362. 
no doubt that in this way Nitti also hoped to obtain some concessions for Italy and to reach a satisfactory solution for the Adriatic question. ${ }^{54}$

At the beginning of 1920, the Supreme Council delivered the peace conditions to the Hungarians and allowed them to present their counterproposals. For a moment, the great powers seemed to be more favorably disposed toward the Hungarians. At the inter-allied conference held in London in February-March 1920, British premier David Lloyd George recognized the gravity of the territorial sacrifices envisioned for Hungary and criticized the peace conditions for attributing a third of the Magyar nation to neighboring countries. Nitti followed suit: "The council could not accept that millions of Magyars were submitted to the sovereignty of other nations without further discussion. [...] At the moment there was a large number of Hungarians outside of their national territory and he urged the council not to forget that even the conquered peoples were entitled to justice." Despite French protests, Lloyd George managed to have the Hungarian peace conditions re-examined in a specific meeting of the allied foreign ministers to be held in the following days, still in London. ${ }^{55}$ In the meantime, in the internal discussions of the Italian delegation, Scialoja pointed out the difficulty of obtaining some concessions in Hungary's favor. After Nitti insisted on the necessity to accomplish something, he expressed the opinion that Italy might have some prospect of success on the border with Czechoslovakia. ${ }^{56}$

When the foreign ministers met, however, the atmosphere had already changed. Pressed by the French and also by the members of the soon to be Little Entente, the British had become more cautious. In this atmosphere, Scialoja's suggestion that the Supreme Council entrust the experts with a new examination of the Hungarian borders was met with sharp denial. The same happened when Vannutelli Rey, the Italian expert who assisted Scialoja, proposed reconsidering at least the Hungarian-Czechoslovak section of the border, mentioning specifically the Grosse Schütt and the area in proximity to Budapest. In the end, the foreign ministers excluded any changes before the signing of the peace treaty but admitted that afterwards the commissions charged with defining the details of the Hungarian border might suggest some minor changes to the League of Nations. ${ }^{57}$

A final discussion took place back in Paris within the Conference of the Ambassadors, the body created for regulating the last details of the peace treaties. After the Americans, who had not taken part in the conference of London, raised their confusion regarding the decisions concerning Hungary and asked for the detachment of Subcarpathian Ruthenia from Czechoslovakia, the Italian representative, Lelio Bonin Longare, gave his support "wholeheartedly". ${ }^{8}$ This attempt also did not bear any fruit, but Bonin did secure the possibility that future territorial changes in Hungary's favor be mentioned in the letter which the victorious powers were to send with the text of the peace treaty to Budapest,

54 CACCAMO 2000, pp. 237-242; MICHELETTA 1999, 1, pp. 88-102.

55 Documents on British Foreign Policy (DBFP). London: His Majesty's Stationary Office, Series 1, Vol. 7, docs. 26 and 46, Conference of London, 25 February and 3 March 1920.

56 ACS, Carte Nitti, b. 32, Nitti to Scialoja, 8 and 9 March 1920, and Scialoja to Nitti, 8 March 1920.

57 DBFP, 1, 7, doc. 54, pp. 440-449, Conference of London, 8 March 1920; ACS, Carte Nitti, bb. 22 and 32, Scialoja to Nitti, 9 and 11 March 1920, Nitti to Scialoja, 10 March 1920, and Nitti to Bonin, 15 March 1920. The danger of Anglo-Italian collaboration in Hungary's favor became one of the main incentives for the coordination of Czechoslovakia with the Kingdom SCS and Romania and for laying down the foundations of the Little Entente: DČZP, A, 2,2 , docs. 539, 556, 568, 569, 570, 572, 578, 586, 603 .

58 ASMAE, Conferenza della Pace, b. 277, Conference of the Ambassadors, 29 March 1920 (No. 26); ACS, Carte Nitti, b. 32, Bonin to Nitti and Scialoja, 30 March 1920. 
the so-called lettre denvoi. At least theoretically, the result was to leave the door open for a partial revision of the Treaty of Trianon..$^{59}$

In this way, the debate concerning the shaping of Czechoslovakia was over. At the Paris Peace Conference, Italy had been the member of the victorious coalition that exhibited the most reservations about the territorial ambitions of the new state and was more intent in trying to avoid their complete fulfillment. This line of conduct was exhibited in the early phases of the conference by the Italian experts or technical representatives in the Commission on Czechoslovak Affairs and was reiterated for over a year, though with some discrepancies, by the various Italian plenipotentiary delegates alternating in the Supreme Council. In the end, the role played by the Italians can bring us to very different interpretations. We can agree with Masaryk, who, as early as the spring 1919, argued that Italy was destined to tie itself to the countries that had been defeated during the war, or with Beneš, who went so far as envisaging the outbreak of a new conflict where Italy and Czechoslovakia would take opposing sides. In this way, the Czechoslovak ruling group seemed to anticipate the scenario that would actually materialize twenty years later, with Mussolini's alignment with Hitler at the conference of Munich and the Italian-German alliance during World War II. But we could also reach a different conclusion. Had Czechoslovakia not taken such advantage of the position of "darling of the Entente" (miláček Dohody, according to the definition proudly employed by Beneš himself), and displayed more moderation toward its neighbors at the peace conference, as suggested by the Italians, perhaps it would not have found itself in such a critical situation at the end of the 1930s.

59 ASMAE, Conferenza della Pace, bb. 277 and 278, Conference of the Ambassadors, 31 March and 12 April 1920 (Nos. 27 and 31); ACS, Carte Nitti, b. 47, Bonin to Scialoja, 31 March 1920, and Bonin to Nitti and Scialoja, 3 and 18 April 1920.

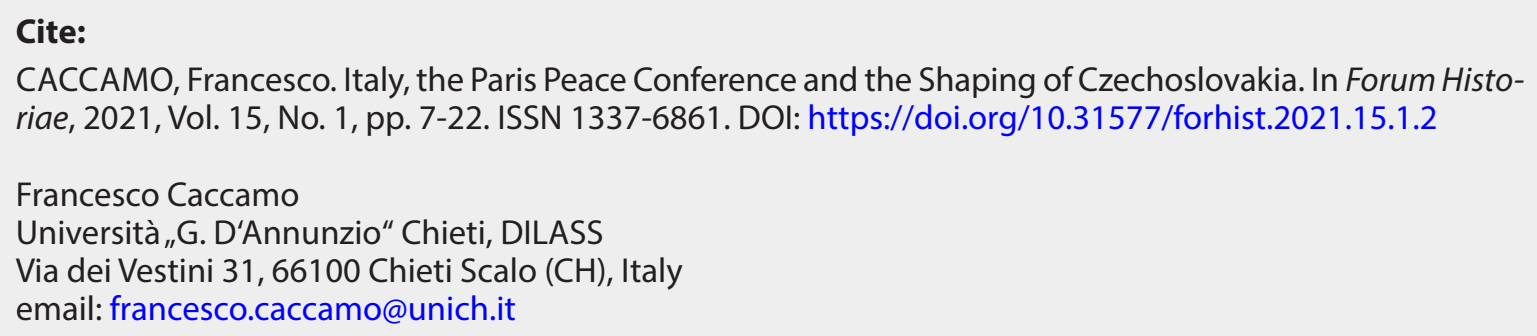

